\title{
The Transcultural Edge
}

\section{Curated by Ilaria Vanni Accarigi, University of Technology Sydney}

Edges as aspects of landscapes have a long history in ecology. The edge is understood as a transition zone between two ecosystems, as an interface between two mediums: 'It is the surface between the water and the air; the zone around a soil particle to which water bonds; the shoreline between land and water; the area between forest and grassland' (Mollison 1978: 26).

Edges are important because they produce certain effects. Resources from both systems can be used, increasing productivity, for instance at the boundary of a forest and grassland. Species from both systems are present at the edge interface, thus increasing biodiversity, such as the edge between coral and ocean. Finally as transition zones edges have unique species, such as those found in mangrove habitats (Mollison 1978: 26; Turner Davidson Hunt \& O’Flaherty 2003: 440).

However more recently edge effects have acquired less positive connotations. Land use and natural or human-generated disturbances produce fragmented landscapes and reduced patches, smaller circumscribed zones with different characteristics from the surrounding areas. Extended edges reduce the habitat of species living at the centre of a patch, and increase the chances of other species spreading (Peters, Gosz \& Collins 462).

Turner, Davidson Hunt and O'Flaherty, writing about Indigenous populations in three edge areas in Canada, and adopting the more positive understanding of edge, have 
proposed that access to ecological edges translates in social and cultural terms as resilience and a richer cultural capital: 'Cultural edges, rather than being border zones between discrete social entities, are zones of social interaction, cross-fertilization, and synergy wherein people not only exchange material goods but also learn from one another' (2003: 440).

Business literature also provides ways to think about edges (Hagel, Seely Brown \& Davison 2010). Edges are defined as those projects and activities on the periphery of a core business, where people experiment, cross-pollinate, tinker and develop innovative ideas. Because of the relative freedom to tinker, the interaction with people outside, and the intermingling of ideas and practices from different fields, these edges, like their ecological counterparts, are richer in diversity and more dynamic than cores. Many technologies we use in our everyday lives were developed at first on the edge of companies. Google maps, Gmail, and Google Apps are examples of this dynamic. iPhones started their life at the edge, as a music player, the iPod, that was supposed to be an accessory to Apple computers.

Edges also provide my starting point to think about ecologies of transcultural processes. By this I mean to recognize that transculturation is not a matter that depends exclusively on humans. Through the flows of migration and globalization edges as transition zones and interfaces are produced. And as in nature the effects they engender can be enriching, as is often theorized in happy hybridity theory, or they can cause struggles, strife, and unbalanced power relations, as many transcultural theorists have pointed out.

One pertinent example comes from current news. As I write, a virus of the family Flaviviridae has arrived in Australia. It was first discovered in Uganda in 1947, in the Zika forest, from which it now takes its name: Zika virus. It is spread through the bite of a tiny mosquito called Aedes (the name means unpleasant in ancient Greek). Zika was also found in some tropical regions of Asia and in French Polynesia, where it contributed to the diversity of mosquito born fevers, but was classified as harmless. Harmless, that is, until 2014, when it travelled to Brazil — coincidentally benefiting, it is said, from the football World Cup that Brazil was hosting in June and July. In Brazil the Zika virus found optimal conditions and reproduced rapidly: at present there are some 1.5 million cases of infected people. The spreading of the virus across the Americas is, according to the World Health Organization, a matter of time (Douglas 2016). The Zika 
virus has been linked to the rise in cases of microcephaly in babies and it has been declared an international public health emergency by the World Health Organization.

The arrival of the Zika virus on the international scene does not only affect global health. It has gendered and social implications, as women, pregnant women in particular, are the most vulnerable group. The virus especially affects women living in poorer areas in the peripheries of North East Brazil, where people store their own rainwater and where rubbish collection is not regular, factors that increase the breeding environment of mosquitos. The hot weather is also a factor, as women tend to wear shorts, increasing the possibility of being bitten and infected by the virus (Douglas 2016). But the Zika virus has also created an epistemological rift: the scientific community in Brazil has very little knowledge of the newly arrived virus, or we could say the Zika virus has disturbed the order of things of scientific knowledge (Watts 20016). Finally, the virus's spread will also produce a chain of effects at the ecological level, as the only solution discussed by Brazilian and other national authorities seems to be the chemical extermination of mosquitos.

Plants, bacteria, virus and animals pop up, altering the order of epistemological, as well as ecological, systems. Objects leave their cultural frames, travel, reconfigure in new assemblages and start a chain of effects. Languages, cultural formations, social practices collide. Ideas, such as transculturation itself, traverse disciplines, question assumptions, generate different ideas, as Paul Allatson demonstrates in his genealogy of the concept of transculturation (2007: 229-232). Allatson draws attention to transculturation's processual character and returns the intellectual development of the concept to its Latin American origins and evolution. Where most postcolonial adaptations of the term often use it as a synonym of hybridity, transculturation from its first theorization described a set of concomitant processes. Cuban anthropologist Fernando Ortiz coined the term transculturation in 1940 to explain the histories of cross-cultural encounters between European and African peoples in Cuba. Ortiz's work was the result of his dissatisfaction with the idea of acculturation - the tacit acquisition of culture - deemed to illustrate a one-way situation, and proposed instead a set of processes including acculturation (cultural acquisition), deculturation (cultural loss), and neoculturation (the emergence of new cultural formations). Other cultural theorists expanded on Ortiz's concept. Nancy Morejón (1982) introduced an analysis of the power struggles implicit in 
transculturation, and highlighted how no group or cultural formation can ever over overrule others. Angel Rama $(1982,1997)$ writing about Latin American literature elaborated transculturation as an analytical mode to query fixed philosophical, literary and cultural ideas. Drawing on Rama, Walter Mignolo (1995) linked transculturation with different and multiple speaking positions.

\section{Mary Louise Pratt, in Imperial Eyes: Writing and Transculturation (1992), used} transculturation to stress the reciprocity of exchanges between colonial centres and peripheries and to query the way in which the peripheries influenced the metropolis, including 'the latter's obsessive need to present and re-present its peripheries and its others continually to itself' (1992: 6). Pratt also offers another useful, and influential, concept: the contact-zone. This describes the entanglement and co-presence of trajectories and people previously separated by geographical and historical factors. In a contact-zone, crucially, power relationships are always uneven. Silvia Spitta (1995) expanded on this lack of symmetry in power relations from a feminist angle, to remind us that colonizing projects in the Americas started with violence against women. As a result, the gendered nature of power needs to be recognized in the discursive arenas of hybridity and mestizaje.

Spitta also opened up the discourse of transculturation to material culture. In her Misplaced Objects, Spitta tells the story of objects that in the process of travelling from one place to another disrupted the established order of things and forced a 'profound reshuffle of the known' (2009: 5). Objects such as Montezuma's headdress, misplaced in Europe and cut loose from the web of meaning and cultural practices that had produced it, engendered by their very presence epistemological rifts, thereby determining a rearranging of categories and taxonomies, and destabilizing certainties (2009 5). For Spitta:

every new cultural configuration and therefore every subject position depends upon transcultural processes: the uprooting of objects, the loss of place and memory that such uprootings entails, the reconfiguration of objects in foreign spaces and the concomitant reorganization of the epistemological table of the receptor culture under the impact of those objects. $(2009: 21)$

In this inaugural curated issue of Portal, I want to open up a space at the edge of academic writing, a site of interrelations, of disciplinary transitions, of cross-pollination 
of diverse orders, and, above all, of tinkering with ideas and modes of writing. I thus present five works that engage with a variety of transcultural edges. I also want to mimic edge dynamics, bringing together elements from two distinct epistemological systems: transcultural theory on one hand, and ecology on the other. This dynamic opens up a series of possibilities to expand the ways we think about transculturation. I ask: how can we consider the work done by things, plants, animals, spaces - all that is more-than human - in processes of transculturation?

Similar questions are asked by Stephanie Springgay in her critical appraisal of Canadian artist Diane Borsato, 'Learning to be Affected in Contemporary Art.' Here Springgay takes her departure point from a corpus of art projects to reflect on affective pedagogies and to argue that learning is not a matter of grasping notions or skills, but rather a matter of movement. In this proposition to learn is to be moved, animated by the multiplicity of things and beings. To illuminate this affective pedagogy, Borsato's work is presented as a series of snapshots that illustrate the artist's concern with practices of embodied learning, or as Springgay writes, borrowing from Bruno Latour (2004): 'learning to be affected.'

We follow Borsato as she transits across diverse cultural formations and practices: working with beekeepers in Italy and learning Italian; working with beekeepers in Ontario and meditating; going mushrooming with mycologists in New York's Chinatown and walking, exploring, as Springgay points out, 'the mobility of thinkingdoing.' The modality of this exploration is ecological: learning to be affected is an embodied pedagogy. Things, animals, spaces, fungi, other humans and their interrelations - from the invisible mycelia of a Canadian forest to the transnational trade flows of exotic mushrooms from Asia to New York-are intrinsic to the way we apprehend the world.

Rox De Luca's contribution is literally the result of objects gathering at the edges, in this case plastic detritus washed up on Sydney's Bondi Beach. In her previous work De Luca investigated histories of migration, concentrating on the transculturation of everyday objects, such as kitchen implements, personal items, or a collection of Italian needlework patterns her mother used to buy. In her recent work, Abundance, Excess, Waste, De Luca maintains a close attention to misplaced objects: fragments of plastic broken up by the ocean and landed from elsewhere in Sydney. It is an investigation of 
an edge - the beach as the transition area between land and ocean — and of one of its effects: the constant making and unmaking of an assemblage of bits of human-made materials. From this edge De Luca generates new assemblages, using jewellery making techniques, as coils of colourful plastic debris strung together with wire. In this process, collecting found objects on a beach, and reorienting them following aesthetic criteria, she questions how bits of colourful plastic can disturb and disrupt the order of things. This question is epistemological: how do we understand colourful garlands of rubbish assembled to look beautiful? And, tragically, material: how does plastic rubbish disrupt marine and land ecosystems?

The southern Californian Susana Chávez-Silverman starts her 'Solstice Hart-Seer: Recordando "La Chascona” y “La Sebastiana' Crónica,' a code-switching crónica - a transcultural and translingual genre per se - by reading a transcultural narrative in the travel section of the New York Times about a writer's visit to Pablo Neruda's houses in Chile. Soon Chávez-Silverman despite herself is drawn into the story, echoing the journalist's sense of being drawn into Neruda's houses by their materiality. The objects dripping with moods and affects unlock Chávez-Silverman's buried memories of her own trip to Chile and to Neruda's houses. Two sets of memories are triggered by looking at the same photographs and remembering the same objects. This and other assemblages (in her own home, for instance) of objects that travelled from somewhere else, narratives and imagination unbend fragments of memory, which unfurl, like - she writes - 'ferns' tendrils.' This unfurling evokes the Unheimliche, the un-homely, one of the traits objects acquire in the process of transculturation. As Spitta writes, when things are uprooted, they lose their place and memory; then they are reconfigured in a new space, and this in turn leads to an epistemological reorganization (2009: 21). If in other works we see this process between cultural formations, in Chávez-Silverman's crónica, objects reconfigure a private epistemology.

Leyla Stevens in her first person visual essay 'Lomba Merpati: Place-making and Communal Signalling within Javanese Pigeon Racing,' offers a narrative of a transcultural encounter and a description of another entanglement between humans and non-humans. Stevens finds herself walking through Yogyakarta while on an artist's residency. For the artist walking is a way to apprehend her new environment and to carve out her own sense of place from the multiplicity of stories and trajectories 
animating the Javanese city. During these wanderings Stevens starts to recognize a particular spatial configuration: sites at the edge of rice fields, or transition areas between one kampung (village or neighbourhood) and another, alongside the river, delimitated by goal posts. These are training grounds for pigeon races. Her narrative brings to mind another famous description of the intense relationship between birds and men in Indonesia, Clifford Geertz's 1973 essay on cockfighting in Bali, 'Deep Play: Notes on the Balinese Cockfight.' Unlike Geertz, who focused on the status and social implications of the game, Stevens concentrates on the relationship between men and pigeons. At dusk men from the kampungs, gather in the training grounds with their pigeons. It is a waiting game, during which men, female birds, objects and the edge between the kampungs, are suspended in the time spent waiting for the male pigeons to return to their owners. While nothing seems to be happening at first sight in the photographs, we slowly understand that Stevens is documenting the reciprocity of pigeon training: pigeons learn from men to fly back, men learn in response to pigeons to move, wait, and act.

Frans Ari Prasetyo, in 'City Performance: Chinese New Year in West Kalimantan,' presents a different type of transcultural entanglement in Indonesia. We are in Kalimantan (Borneo), in the city of Singkawang, a city unique in Indonesia in having a Chinese majority. The Chinese New Year local festival, documented in a series of photographs, gives the opportunity for Prasetyo to start a reflection on the complex role played by the event in the negotiation of relationships between China and Indonesia at a macro level, and between Dayak (the Indigenous people of Kalimantan ) and Chinese populations on the other. Prasetyo's presentation of the festival generates three meanings. The first meaning is the festival as an index of historical changes in the Indonesian government's legal treatments of its Chinese-origin peoples, treatments that are shadowed by shifting foreign policy and international relations with China. The second meaning is as a site, or stage, of transculturation and the constantly negotiated power relations between Chinese, Dayak and Malay peoples in the city. The third is as a successful performance of civic unity during which the city generates a self representation based on a cosmopolitan imaginary. Prasetyo complements these overlapping readings with a detailed visual ethnography of the festival, showing how a Chinese cultural practice is embodied in a specific historical and cultural local context. The festival could thus be understood as a transcultural edge, a site where unevenly 
distributed different cultural systems, representation, imaginaries converge and give rise to new transcultural practices.

\section{Reference List}

Allatson, P. 2007, 'Transculturation,' Key Terms in Latino/a Cultural and Literary Studies. Blackwell Publishing, Malden, MA and Oxford: 229-232.

Douglas, B. 2016, 'City at Centre of Brazil's Zika Epidemic Reeling from Disease's Insidious Effects,' The Guardian, 25 January. Online, available: http://www.theguardian.com/globaldevelopment/2016/jan/25/zika-virus-mosquitoes-countries-affected-pregnant-women-childrenmicrocephaly [accessed 5 February 2015].

Geertz, C. 1973, 'Deep Play: Notes on the Balinese Cockfight,' The Interpretation of Cultures: Selected Essays. Basic Books, New York, 1973: 412-453.

Hagel III, J., Seely Brown, J. \& Davison, L. 2010, The Power of Pull: How Small Moves, Smartly Made, Can Set Big Things in Motion. Basic Books, New York.

Latour, B. 2004, 'How to Talk About the Body? The Normative Dimension of Science Studies,' Body \& Society, vol. 10, no. 2-3: 205-229. doi: http://dx.doi.org/10.1177/1357034X04042943.

Louise, P. M. 1992, Imperial Eyes. Travel Writing and Transculturation. Routledge, London \& New York.

Mignolo, W. 1995, The Darker Side of the Renaissance: Literacy, Territoriality, and Colonization. University of Michigan Press, Ann Arbor.

Mollison, B. 1978, Permaculture 1: A Perennial Agricultural System for Human Settlements. Transworld Publishers, Melbourne.

Morejón, N. 1982, Nación y mestizaje en Nicolás Guillén. Rodríguez Feo, Havana.

Ortiz, F. 1940, Contrapunteo cubano del tabaco y el azúcar. J. Montero, Havana.

Peters, D. P. C., Gosz, J. R. \& Collins, S.L. 2009, 'Boundary Dynamics in Landscapes,' in The Princeton Guide to Ecology, (ed.) S. A. Levin. Princeton University Press, Princeton, NJ: 458-463.

Rama, A. 1982, Transculturación narrativa en America Latina. Siglo Veintiuno, Mexico City.

Rama, A. 1997, 'Processes of Transculturation in Latin American Narrative' trans. M. Moore, Journal of Latin American Cultural Studies, vol. 6, no. 2: 155-171. doi: http://dx.doi.org/10.1080/13569329709361909.

Spitta, S. 1995, Between Two Waters: Narratives of Transculturation in Latin America. Rice University Press, Houston, TX.

Spitta, S. 2009, Misplaced Objects: Migrating Collections and Recollections in Europe and the Americas. University of Texas Press, Austin.

Turner, N. J., Davidson-Hunt, I. J. \& O'Flaherty, M. 2003, 'Living on the Edge: Ecological and Cultural Edges as Sources of Diversity for Social-Ecological Resilience,' Human Ecology, vol. 31, no. 3: 439-461. doi: http://dx.doi.org/10.1023/A:1025023906459.

Watts, J. \& Boseley, S. 2016, 'Scientific Ignorance about Zika Parallels Aids Crisis in 1980s, Say Brazilian Experts,' The Guardian, 2 February. Online, available: http://www.theguardian.com/world/2016/feb/02/zika-virus-scientific-research-lacking-latinamerica [accessed 5 February 2016]. 